\title{
GALERI SENI KALIGRAFI ISLAM DI MARTAPURA
}

\author{
Noor Hasnawati \\ Program Studi Teknik Arsitektur Fakultas Teknik Universitas Lambung Mangkurat \\ Noor.hasnawati022@gmail.com \\ Muhammad Deddy Huzairin \\ Program Studi Teknik Arsitektur Fakultas Teknik Universitas Lambung Mangkurat \\ deddyhuz@yahoo.com
}

\begin{abstract}
ABSTRAK
Galeri Seni Kaligrafi Islam adalah tempat yang mewadahi karya seni kaligrafi untuk mempermudah masyarakat dalam mengenal, mempelajari dan memperoleh salah satu Seni Kebudayaan Islam yaitu Kaligrafi. Tujuan tersebut dapat dicapai dengan cara mewujudkan desain yang dapat menarik perhatian dan dapat mengenalkan kaligrafi Islam kepada masyarakat serta berlokasi strategis. Sehingga, Galeri Seni kaligrafi Islam yang akan dirancang adalah galeri di Martapura yang ekspresif dan edukatif terhadap seni kaligrafi Islam dengan cara menerapkan unsur-unsur kaligrafi kedalam bentuk, ruang dan tatanan arsitektur. Permasalahan tersebut dijawab menggunakan metode metafora konkret dan abstrak. Kaligrafi islam merupakan bentuk rangkaian huruf tunggal yang tersusun dengan komposisi yang indah. Selain itu, Kaligrafi Islam juga mengandung filosofi tentang makna yang dikandungnya. Bentuk dan filosofi kaligrafi Islam dianalisis kedalam ruang, bentuk dan tatanan arsitektur untuk menciptakan desain galeri yang edukatif dan ekspresif. Unsur-unsur kaligrafi islam digambarkan dalam bentuk massa bangunan, tekstur, warna, dan facade (metafora konkret). Sedangkan filosofi atau makna kaligrafi digambarkan pada orientasi massa, pencapaian, sirkulasi, ruang dan sequence flow (metafora abstrak).
\end{abstract}

Kata kunci: Galeri, Kaligrafi Islam, Metafora, Edukatif, Ekspresif.

\begin{abstract}
Islamic Calligraphy Art Gallery is a place that accommodates calligraphy artworks to make it easier for people to know, learn and obtain one of the Islamic Cultural Arts namely Calligraphy. This goal can be achieved by realizing a design that can attract attention and can introduce Islamic calligraphy to the community and is strategically located. Thus, the Islamic Calligraphy Art Gallery that will be designed is a gallery in Martapura that is expressive and educational towards Islamic calligraphy art by applying calligraphy elements into the form, space and architectural order. The problem is answered using concrete and abstract metaphorical methods. Islamic calligraphy is a single series of letters composed with beautiful compositions. In addition, Islamic Calligraphy also contains a philosophy about the meaning it contains. Islamic calligraphy forms and philosophies are analyzed into spaces, shapes and architectural settings to create educational and expressive gallery designs. Elements of Islamic calligraphy are depicted in the form of building masses, textures, colors, and facades (concrete metaphors). While the philosophy or meaning of calligraphy is described on mass orientation, achievement, circulation, space and sequence flow (abstract metaphor).
\end{abstract}

Keywords: Galery, Islamic Caligraphy, Metaphor, Education, Expression. 


\section{PENDAHULUAN}

Tingkat pengetahuan dan minat masyarakat terhadap seni Islam yang masih minim menjadi salah satu penyebab kurang tingginya apresiasi masyarakat terhadap Seni Islam terutama Kaligrafi. Masyarakat harus menunggu diadakannya suatu pameran khusus yang hanya dilaksanakan pada waktu tertentu untuk melihat dan membeli karya seni Kaligrafi yang banyak ragamnya. Disamping itu, fenomena yang sekarang sering terjadi adalah terkadang masyarakat lebih memilih tempat-tempat yang menjadi kunjungan favorit yang lagi trend di masa itu. Hal ini sangat disayangkan karena kebanyakan tempat favorit tersebut hanya dikunjungi dengan tujuan berswafoto dan bersenang-senang tanpa memiliki unsur edukasi.

Martapura adalah salah satu kota di Banjarbaru yang terkenal dengan kekentalan Islamnya. Selain dikenal dengan santrinya yang banyak, Martapura juga memiliki kegiatan keagamaan yang sudah menjadi tradisi yaitu "Haul Guru Sekumpul". Tradisi ini dihadiri oleh ratusan ribu orang yang berkunjung ke kota Martapura. Selain itu, Martapura juga menjadi kota yang sering dikunjungi oleh umat muslim yang berasal dari dalam maupun luar kota dengan tujuan ziarah ke makam Guru Sekumpul. Hal tersebut dapat menjadi potensi bagi galeri seni Kaligrafi untuk mempublikasikan koleksi karya- karya seniman kaligrafi yang ada.

Dengan adanya galeri seni Kaligrafi, maka seni kaligrafi akan memiliki satu tempat khusus yang menghimpun segala jenis karya dan informasi mengenai seni kaligrafi. Hal tersebut akan mempermudah masyarakat dalam mencari, mempelajari dan menambah wawasan mengenai Seni Islam yaitu Kaligrafi guna memberikan dorongan yang intensif untuk mengingati dan memuji Allah SWT. Selain itu, galeri juga akan menjadi media bagi seniman kaligrafer/khattat yang ada di Martapura dan sekitarnya untuk meningkatkan promosi akan keberadaan karyanya. Hal tersebut juga dapat menambah kunjungan wisata islami di kabupaten Banjar khususnya Martapura.

\section{PERMASALAHAN \\ ARSITEKTUR}

Bagaimana rancangan galeri di Martapura yang ekspresif dan edukatif terhadap seni kaligrafi Islam dengan cara menerapkan unsur-unsur kaligrafi Islam kedalam bentuk, ruang dan tatanan arsitektur.

\section{TINJAUAN PUSTAKA}

\section{A. Tinjauan Galeri}

\section{Pengertian Galeri}

Galeri adalah bangunan dengan ruang yang dirangkai khusus untuk mewadahi pameran sebuah karya seni. Galeri juga memiliki fungsi lain diantaranya pelayanan publik dalam bidang seni berupa rekreasi, edukasi, ataupun kepentingan komersial.

\section{B. Tinjauan Kaligrafi Islam}

\section{Pengertian Kaligrafi Islam}

Arti kata kaligrafi secara umum yaitu tulisan indah. Dalam bahasa inggris, kaligrafi disebut dengan calligraphy dan dalam bahasa arab disebut dengan khat.

Definisi lebih lengkap disebutkan didalam kitab Irsyad Al-Qasid oleh Syekh Syamsuddin Al-Akhfani yaitu "kaligrafi merupakan ilmu yang mengenalkan bentuk-bentuk huruf tunggal, Letak-letaknya, dan tata cara merangkainya membentuk suatu tulisan yang tersusun, teknik penulisannya, menentukan yang perlu dan tidak perlu untuk ditulis, serta cara menggubah sebuah ejaan. (Sirojuddin, 2000: 3).

\section{Perkembangan Seni Kaligrafi} Islam

Seniman seni kaligrafi di Indonesia memiliki perkembangan periode kaligrafi sendiri diantaranya:

1. Periode Angkatan Perintis

Awal periode dari angkatan ini adalah saat kaligrafi ditemukan pada sebuah makam yang berasal dari luar. Kemudian pada abad 18-20, seniman kaligrafi mulai memperluas media tulis mereka seperti pada kertas, kayu, dan logam serta media lainnya. Pada periode ini kaligrafer memiliki kecenderungan 
menuliskan kaligrafi yang menyerupai makhluk bernyawa.

\section{Periode Angkatan \\ Pesantren}

Pada periode ini kaligrafi menjadi salah satu pelajaran yang diajarkan di pesantren, sehingga perkembangan kaligrafi juga mengikuti perkembangan pesantren. Seiring berjalannya waktu, pesantren mulai melahirkan khattath yang mengkhususkan diri pada penulisan mushaf, buku agama, dan dekorasi masjid dengan menggunakan gaya-gaya Tsuluts, Naskhi, Farisi, Diwani Jali, Diwani, Kufi, dan Riq'ah.

3. Periode Angkatan Pelukis \& Pendobrak

Pada periode ini, kaligrafi mulai menarik perhatian masyarakat. Kemudian muncul sebuah gerakan yang menyadarkan seniman kaligrafi untuk lebih mengembangkan kaligrafi baik itu dari segi teknik maupun media kaligrafi. Gerakan inilah yang kemudian melahirkan para pelukis yang mempopulerkan 'lukisan kaligrafi' yang cenderung

mendobrak 'kaligrafi tradisional' atau 'kaligrafi murni' yang penulisannya memiliki beberapa aturan.

\section{Periode Angkatan Kader MTQ}

Angkatan yang terakhir yang berkembang hingga kini adalah angkatan kader Musabaqah Tilawatil Quran. MTQ merupakan sebuah lomba yang semenjak diadakannya seni kaligrafi menjadi semakin semarak. MTQ ini dilombakan dari tingkat daerah sampai tingkat nasional di seluruh Indonesia.

\section{Filosofi Kaligrafi}

Titus Burckhardt (1976)

menggambarkan kaligrafi dalam dua dimensi yaitu vertikal dan horizontal. Dalam dimensi vertikalnya, setiap huruf memiliki martabat yang hieratik dan dimensi horizontal menjadikan huruf saling terhubung. Dimensi vertikal dari huruf tidak akan pernah berubah, bagaimanapun ia ditulis dan dipakai dalam berbahasa. Sedangkan dimensi horizontal huruf akan terus berubah.

Sedangkan kaligrafi pada tulisan bahasa Arab dari nama Allah terdapat tiga karakter simbolik yaitu garis horisontal dari arah gerak penulisannya, garis vertikal dari goresan Alif dan Lam yang tegak lurus, serta adanya suatu garis melingkar yang secara simbolik dapat diartikan sebagai lingkaran. Menurut Nasr, tiga karakter tersebut menunjukkan tiga dimensi yaitu: ketenangan yang "horizontal" dan tak ubahnya seperti gurun atau lapisan salju: kekuasaan yang "vertikal" bagai kokohnya gunung: dan misteri yang memanjang "ke dalam" serta berhubungan dengan Zat Allah.

\section{Pengertian Edukatif \& Ekspresif}

Pada perancangan ini, tema edukatif yang dimaksud adalah edukasi mengenai seni kebudayaan Islam yaitu Kaligrafi Islam. Adapun pengertian edukasi seni secara rinci dijelaskan oleh Linderman (1984 dalam jurnal Triyanto 2014:38) yaitu, pendidikan seni memiliki tujuan untuk menanamkan nilai estetis dengan cara memberikan pengalaman perceptual, Cultural, dan artistik.

Secara harfiah ekspresif diartikan sebagai salah satu bentuk komunikasi yang menggunakan tampilan-tampilan visual untuk menyampaikan maksud dan tujuannya kepada pengamat. Oleh karena itu, ekspresif berhubungan dengan indera penglihat yaitu sejauh mana kesan yang ditimbulkan bisa dipahami oleh pengamat, baik itu bentuk, warna, maupun material.

\section{PEMBAHASAN}

\section{A. Lokasi Tapak}

Galeri ini dibangun pada sebuah tapak yang terletak di kota Martapura tepatnya di Jl. Ahmad Yani, Kecamatan Martapura, Kelurahan Sungai Paring, Kabupaten Banjar, Kalimantan Selatan. Pemilihan lokasi ini adalah karena merupakan daerah yang memiliki fungsi daerah yang strategis dan potensial untuk tujuan dan fungsi sebuah galeri.

\section{B. Kondisi, Luasan, dan Batasan} Tapak

Keadaan topografis pada wilayah ini relatif datar dengan jenis tanah yaitu tanah keras. Sekitar tapak didominasi bangunan dengan fungsi perumahan, komersil, perkantoran, pendidikan dan sarana umum. Ketinggian bangunan sekitar adalah satu sampai tiga lantai. 


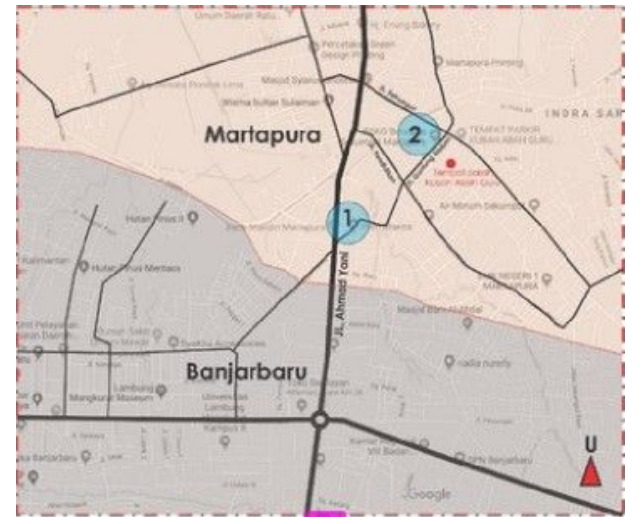

Gambar 1. Lokasi Tapak

Sumber: http://maps.google.co.id (diakses 2019)

Tapak berada pada jalan Ahmad Yani yang merupakan jalan arteri. Jarak garis sempadan bangunan (GSB) jalan arteri berdasarkan ketentuan yang ada adalah $25 \mathrm{~m}$ dari as jalan. Sedangkan intensitas bangunan pada suatu kawasan diatur melalui Koefisien Dasar Bangunan (KDB), Koefisien Lantai Bangunan (KLB). Penetapan KDB disesuaikan dengan karakteristik fungsi bangunan. Untuk bangunan dengan fungsi komersial dan wisata diatur KDB yaitu $60 \%$ dengan luas tapak +1,3 Ha, maka luas area tapak yang terbangun adalah sekitar $7.800 \mathrm{~m} 2$.

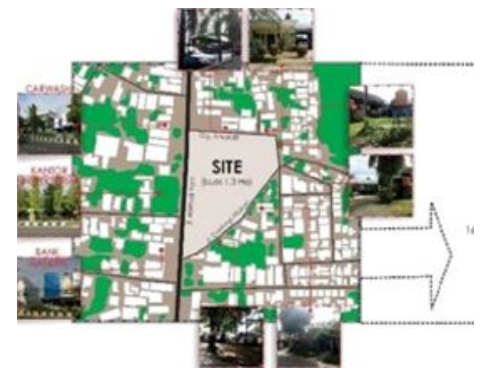

Gambar 2. Eksisting dan Batasan Tapak Sumber: Sintesa penulis dari http://maps.google.co.id dan hasil survey

\section{Konsep Programatik}

Solusi permasalahan arsitektur yang diterapkan pada perancangan Galeri Seni Kaligrafi adalah mewujudkan galeri yang mampu memberikan gambaran, maksud, dan gagasan maupun perasaan kepada pengamat mengenai seni kaligrafi islam dalam bentuk visual (ekspresif). Serta menanamkan nilai estetis dengan memberi pengalaman perseptual, kultural, dan artistic kepada pengamat (edukatif).

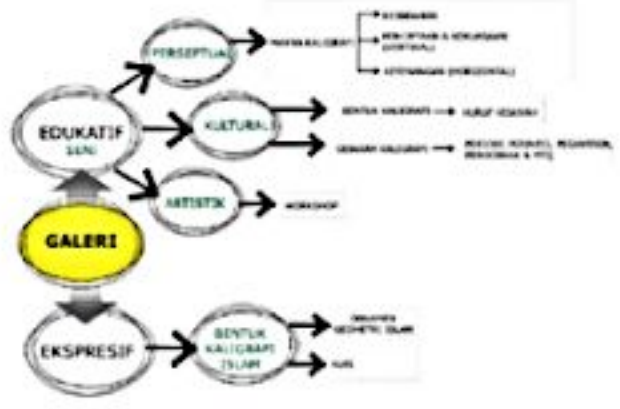

Gambar 3. Konsep Programatik

Galeri yang ekspresif terhadap seni kaligrafi islam diwujudkan dengan menerapkan ornamen geometri Islam yang seringkali menjadi hiasan untuk melengkapi keindahan seni kaligrafi islam. Selain itu galeri ini juga menggunakan bentuk kaligrafi kufi sebagai facade. Sedangkan galeri yang edukatif diwujudkan dengan memberikan pengalaman perseptual kepada pengunjung dengan cara memicu imajinasi tentang makna kaligrafi yaitu keindahan, penciptaan \& kekuasaan serta ketenangan dan memberikan pengalaman kultural dengan menghadirkan bentuk-bentuk dasar kaligrafi islam yaitu huruf hijaiyah dan mengedukasi mengenai sejarah kaligrafi, serta memberikan pengalaman artistik yang dikembangkan melalui pemahaman dan keterampilan menggunakan media seni kaligrafi dan mengapresiasi karya seni seniman kaligrafi dengan menyediakan tempat untuk kegiatan workshop.

\section{Konsep Desain Rancangan}

1. Konsep Bentuk

Bentuk dasar bangunan galeri seni kaligrafi diadopsi dari bentuk-bentuk kaligrafi dan unsur-unsurnya. Pemilihan ide bentuk ini didasarkan pada konsep ekspresif yaitu memberikan kesan visual mengenai seni kaligrafi Islam. 


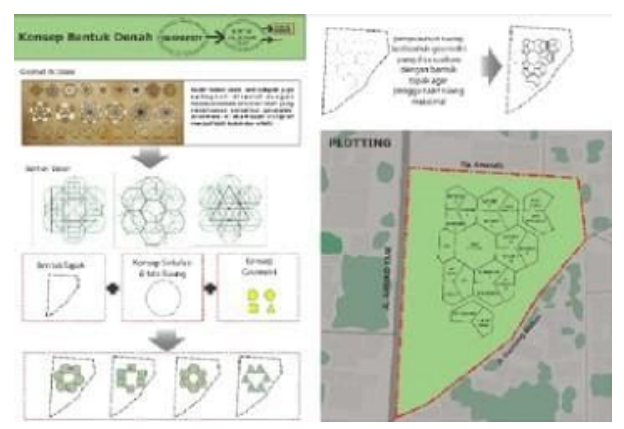

Gambar 4. Konsep Bentuk Denah

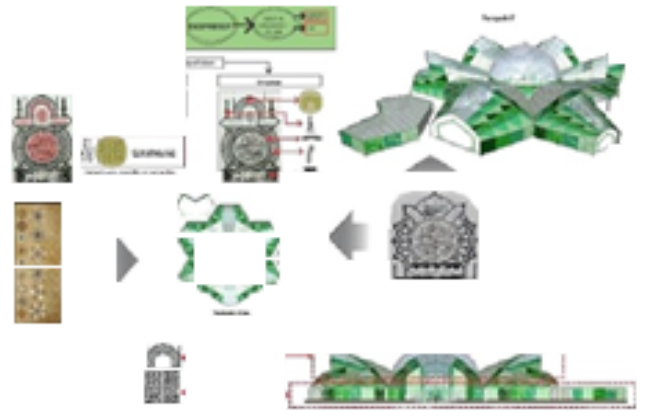

Gambar 5. Konsep Bentuk Massa Bangunan

2. Konsep Ruang

Konsep utama galeri seni kaligrafi Islam adalah ekspresif dan edukatif terhadap seni kaligrafi Islam. Penataan ruang-ruang yang diterapkan adalah radial, yaitu ruang- ruang yang ada pada galeri ini diakses dari sebuah ruang bersama yang ada di pusat bangunan. Ruang bersama ini memberikan kesan dari makna filosofi kaligrafi yaitu makna vertikal (kekuasaan dan keagungan Allah terhadap makhluknya) dengan meletakkan sclupture bertuliskan Allah dan Al-insan.

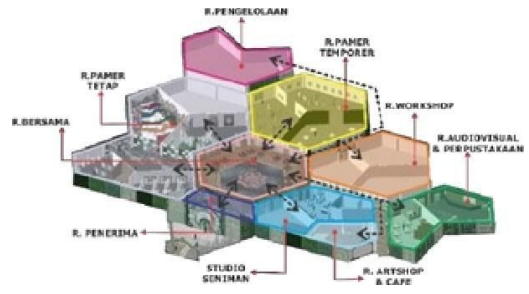

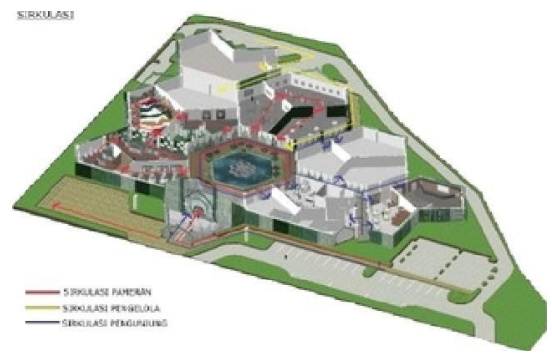

Gambar 6. Konsep Penataan Ruang

Sedangkan sirkulasi pameran adalah linier, hal ini untuk mempermudah pengunjung mengikuti alur periode yang merupakan dasar penyusunan ruang pamer permanen.

\section{Gambar 7. Konsep Sirkulasi Ruang}

\section{Konsep Interior}

Mengedukasi pengunjung mengenai Sejarah perkembangan Kaligrafi di Indonesia melalui tampilan interior, tata cara display dan sequence pameran. Menurut AR Sirajuddin terdapat 4 periode perkembangan Kaligrafi di Indonesia yaitu Periode Perintis, Periode Pesantren, Periode Pendobrak, dan Periode MTQ. Oleh karena itu ruang pamer permanen dibagi menjadi 4 bagian berdasarkan periode perkembangan kaligrafi. Konsep edukatif lainnya adalah dengan mengedukasi makna filosofi kaligrafi yaitu penciptaan (makna vertikal) dengan memberikan kesan alami pada bangunan, kekuasaan (makna vertikal) dengan menghadirkan sculpture sebagai center bangunan, dan ketenangan (makna horizontal) dengan pengadaan unsur air yang tenang. Konsep tersebut dapat dilihat sebagai berikut: 


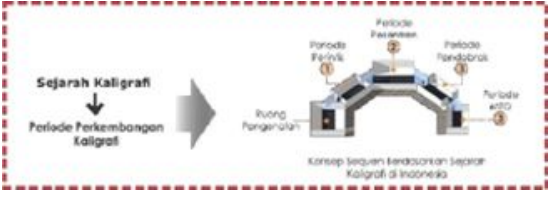

Gambar 8. Konsep Interior

Setiap ruang pamer permanen memiliki suasana dan kesan berbeda sesuai dengan periode perkembangan kaligrali. Hal tersebut dapat dilihat sebagai berikut:
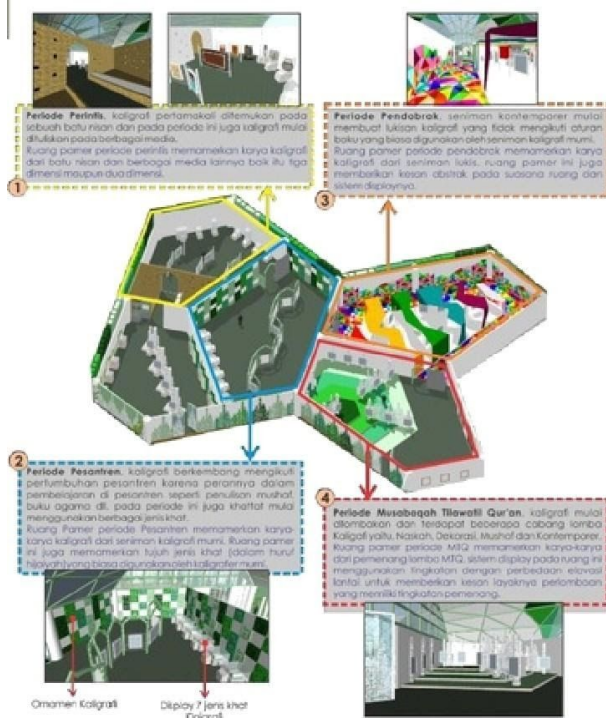

Gambar 9. Konsep Elemen-elemen Ruang Dalam

Sedangkan penetapan makna filosofi kaligrafi terhadap elemen ruang dapat dilihat sebagai berikut:
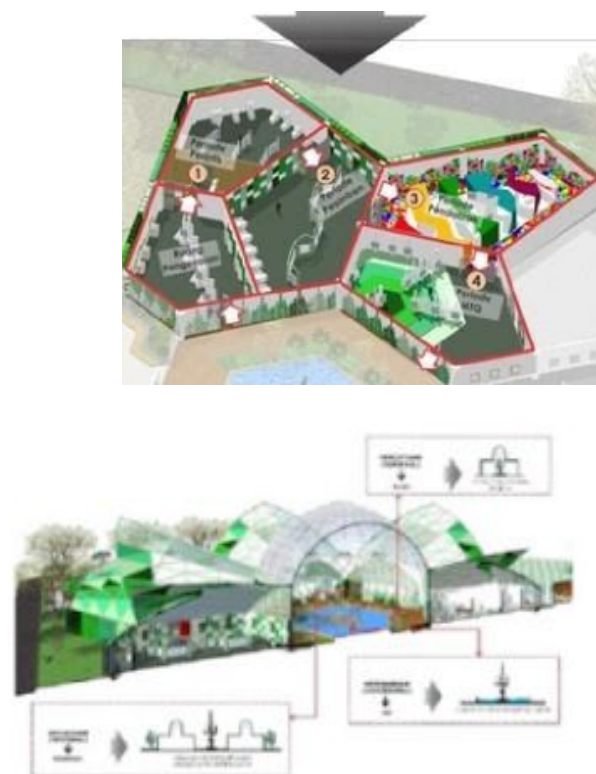

Gambar 10. Konsep Makna Filosofi Kaligrafi

4. Konsep Eksterior

Seni Kaligrafi adalah seni merangkai tulisan bahasa arab. Huruf-huruf Hijaiyah adalah hal yang harus dikenali dalam seni kaligrafi karena huruf Hijaiyah merupakan komponen utama dalam penulisan Kaligrafi. oleh karena itu, sculpture huruf Hijaiyah diletakkan di entrance utama Galeri ini

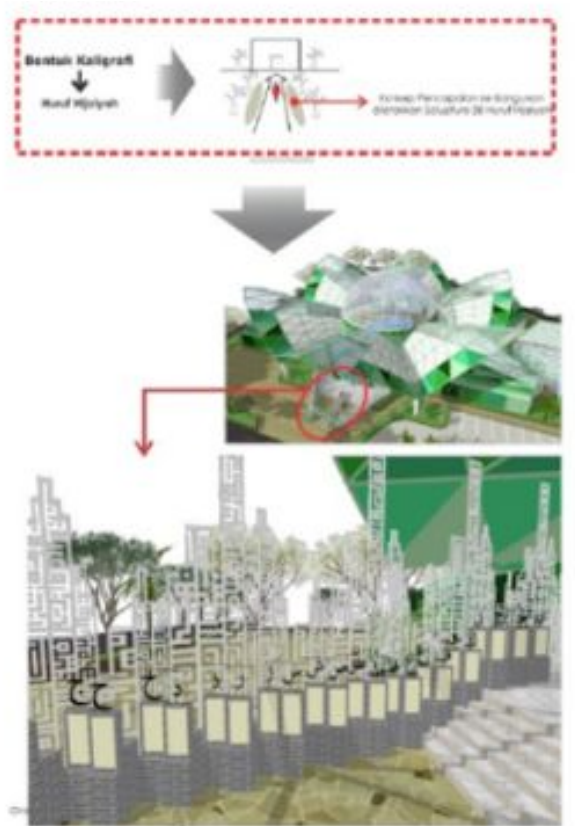


Gambar 11. Konsep Elemen-elemen Eksterior

5. Konsep Struktur dan Konstruksi

Struktur bawah yang digunakan adalah struktur yang sesuai dengan kondisi tanah keras yaitu dengan menggunakan pondasi telapak. Struktur tengah menggunakan struktur dinding bata dan partisi. Struktur atas menggunakan struktur yang sesuai dengan konsep yaitu space frame, truss frame dan kubah. Pemilihan struktur space frame karena struktur ini selain ringan juga dapat menciptakan bentuk atap yang sesuai dengan konsep. Bahan penutup atap adalah enamel steel panel dan kaca laminated.

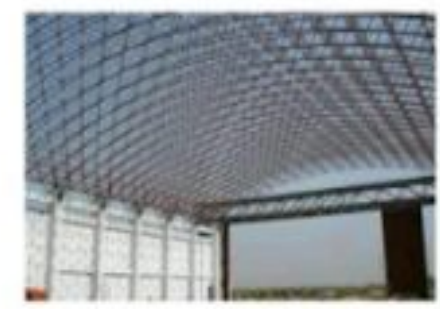

Gambar 12. Konsep Struktur Atap

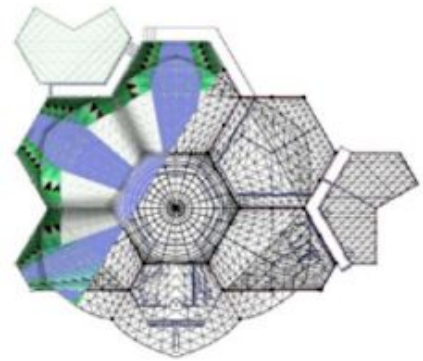

Gambar 13. Rencana Atap

Konstruksi lantai yang digunakan adalah menggunakan konstruksi plat lantai cor beton Dengan finishing keramik, batu alam, vinyl, karpet, cat epoxy dan kayu

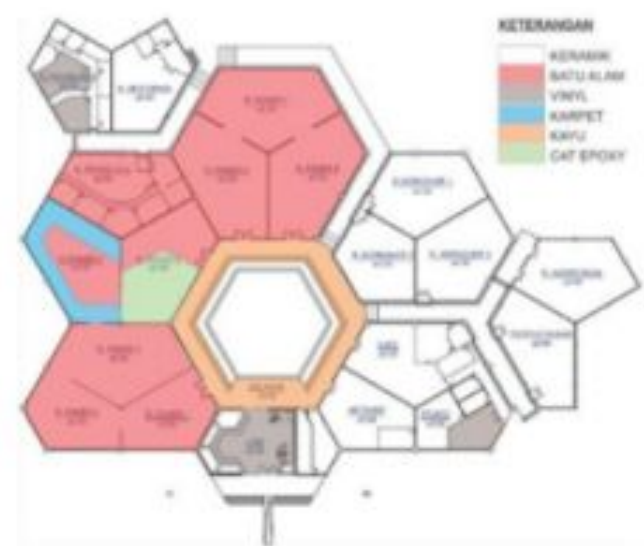

Gambar 14. Konsep Konstruksi Penutup Lantai

Penerapan konstruksi dinding disesuaikan dengan fungsi ruang serta konsep. Macam bahan dinding yang digunakan dapat dilihat sebagai berikut:

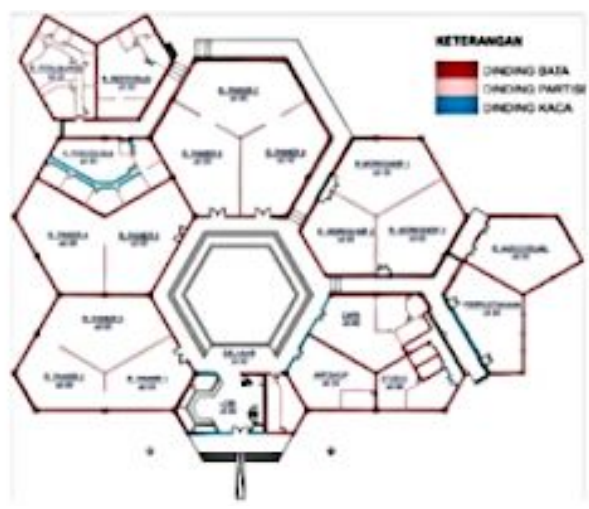

Gambar 15. Konsep Konstruksi Dinding

\section{RANCANGAN}

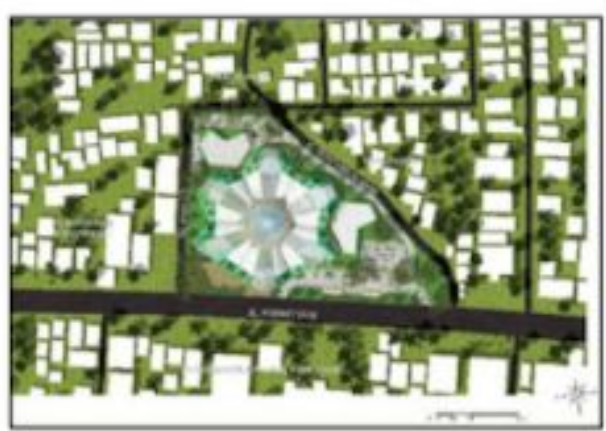

Gambar 16. Gambar Situasi 


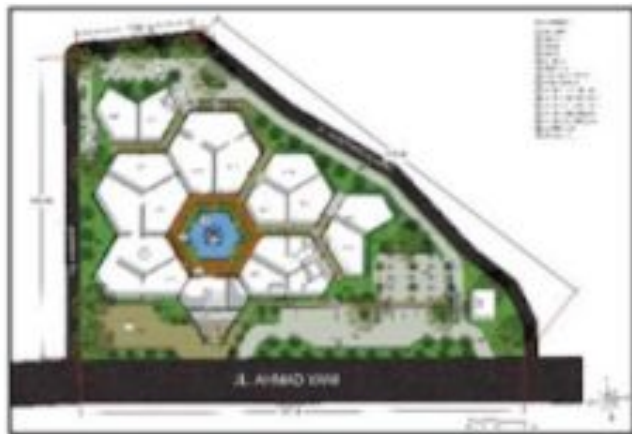

Gambar 17. Gambar Renacana Tapak

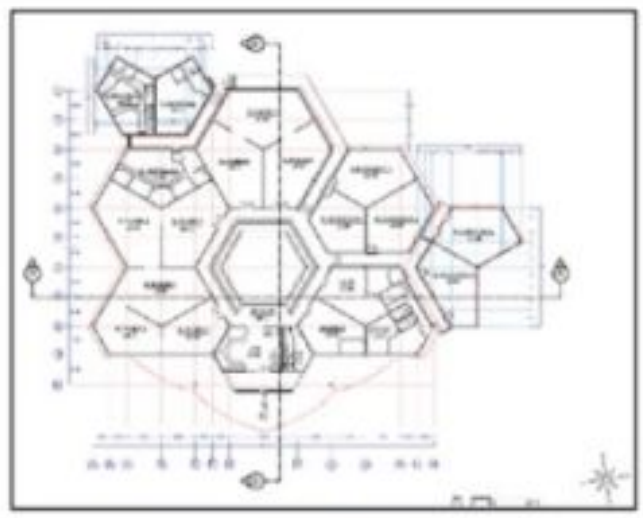

Gambar 18. Gambar Denah

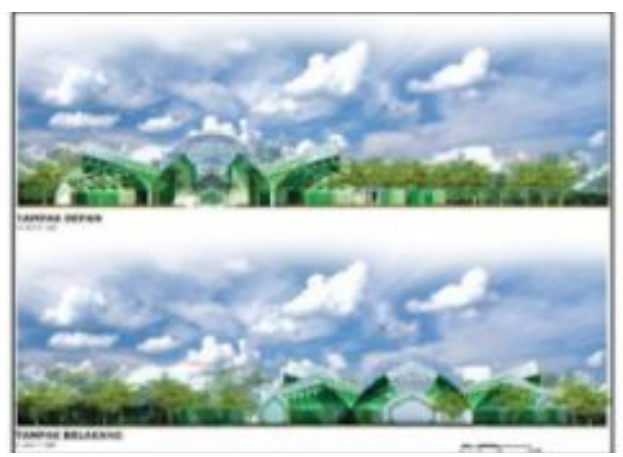

Gambar 19. Gambar tampak Depan dan Belakang

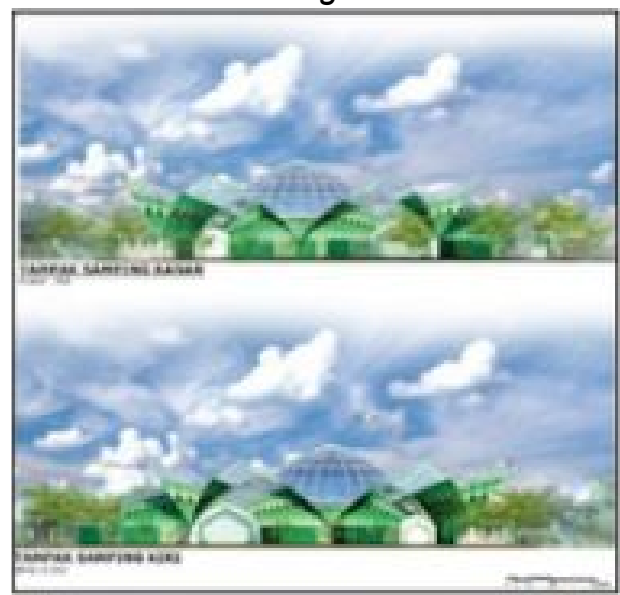

Gambar 20. Gambar Tampak Samping Kiri dan Samping Kanan

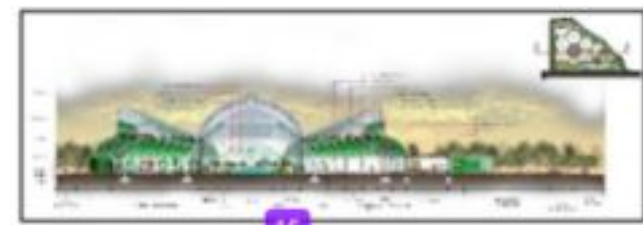

Gambar 21. Gambar Potongan A-A

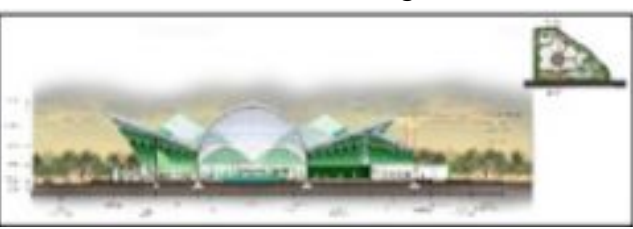

Gambar 22. Gambar Potongan B-B

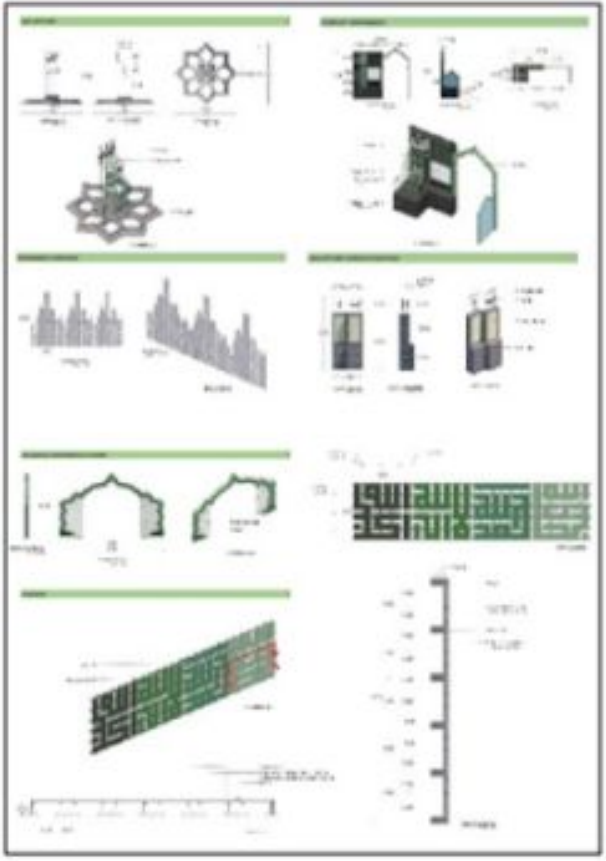

Gambar 23. Gambar Detail Arsitektural

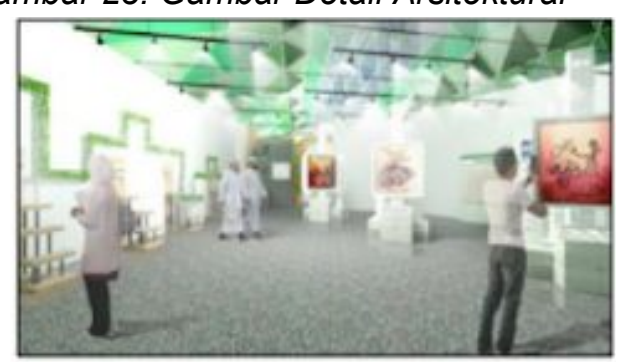

Gambar 24. Gambar Perspektif Ruang Pamer Pengenalan

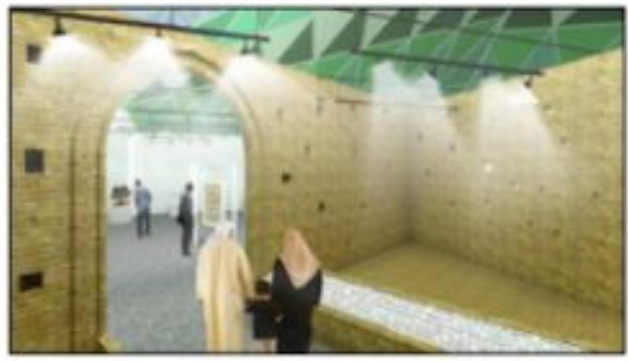

Gambar 25. Gambar Perspektif Ruang Pamer Periode Perintis 


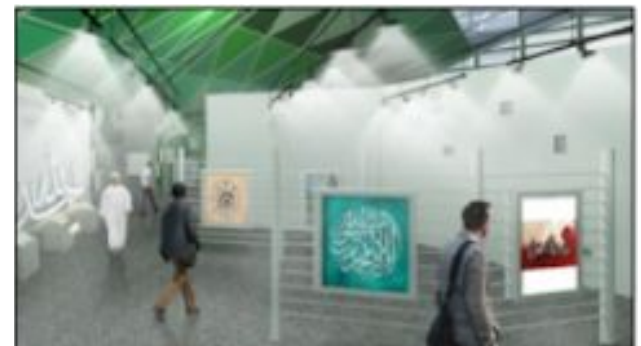

Gambar 26. Gambar Perspektif Ruang Pamer Periode Perintis

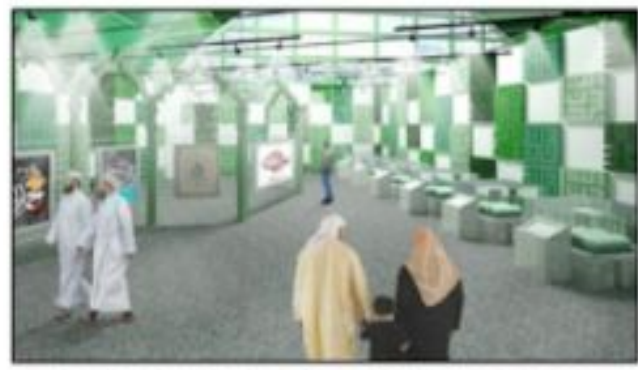

Gambar 27. Gambar Perspektif Ruang Pamer Periode Pesantren

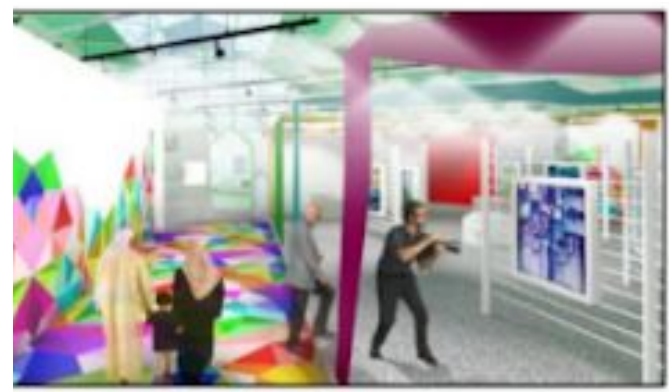

Gambar 28. Gambar Perspektif Ruang Pamer Periode Pendobrak/Pelukis

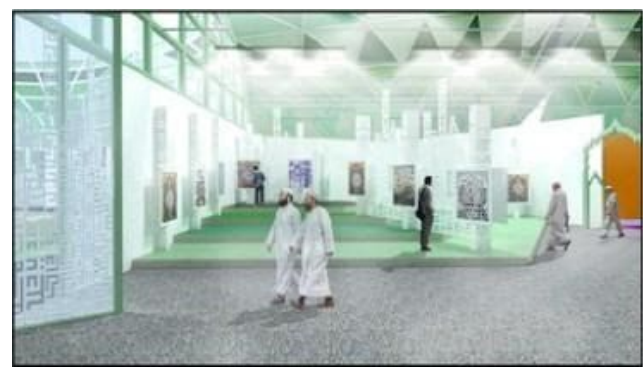

Gambar 29. Gambar Perspektif Ruang Pamer Periode MTQ

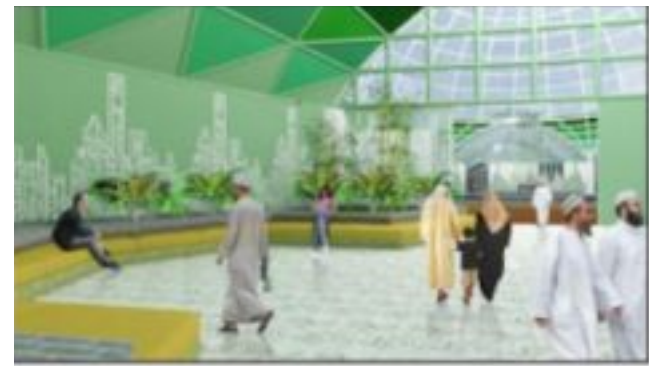

Gambar 23. Gambar Perspektif Lobi

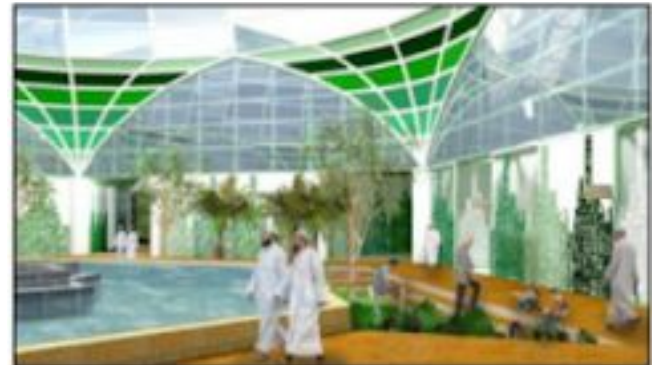

Gambar 23. Gambar Perspektif Ruang Bersama

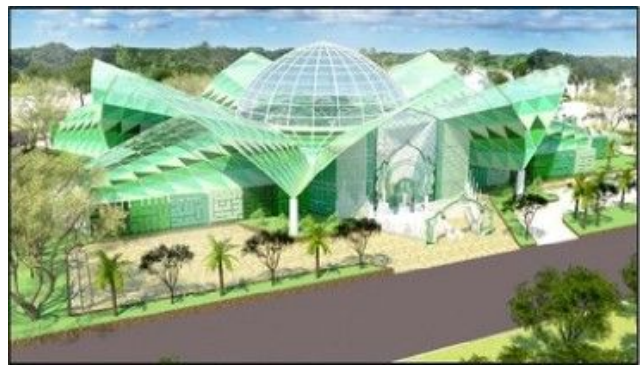

Gambar 23. Perspektif Eksterior

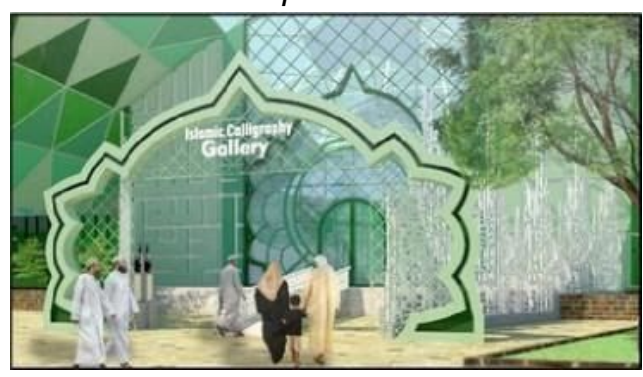

Gambar 23. Perspektif Eksterior Entrance Utama

\section{KESIMPULAN}

Perancangan Galeri seni kaligrafi Islam di Martapura yang ekspresif dan edukatif diwujudkan dengan menggunakan metode metafora.

Desain galeri yang ekspresif terhadap seni kaligrafi islam ditunjukkan pada bentuk denah dan massa bangunan. denah bangunan mengekspresikan ornamen kaligrafi islam, sedangkan massa, fasad dan interior bangunan mengekspresikan ornamen kaligrafi islam dan bentuk kaligrafi kufi.

Desain galeri yang edukatif terhadap seni kaligrafi islam ditunjukkan dengan:

1. Desain galeri yang edukatif (perseptual): 
- Warna bangunan monokromatik yang mengedukasi mengenai makna keindahan yang terkandung dalam seni kaligrafi.

- Desain taman dan sculpture 'Allah' sebagai center bangunan yang mengedukasi makna vertikal kaligrafi (penciptaan \& kekuasaan).

- Desain yang menggunakan unsur air yang mewakili sifat tenang, mengedukasi makna horizontal kaligrafi (ketenangan).

2. Desain galeri

yang edukatif(kultural):

- Desain sekuen ruang pamer permanen yang disusun berdasarkan periode

perkembangan kaligrafi dan suasana ruang permanen tersebut didesain berbeda sesuai dengan periode masing-masing. Hal ini guna mengedukasi pengunjung mengenai sejarah perkembangan kaligrafi di indonesia.

- Desain entrance utama galeri yang disertai dengan bentuk-bentuk huruf hijaiyah. Entrance utama merupakan tempat pertama yang dilalui sebelum memasuki bangunan. Hal ini guna mengedukasi pengunjung bahwa huruf hijaiyah merupakan dasar dan hal pertama yang perlu dikenali dalam seni kaligrafi Islam.

3. Desain galeri yang edukatif (artistik):

- Galeri seni kaligrafi islam ini menyediakan ruang-ruang workshop. Ruang workshop akan memberikan pemahaman dan keterampilan kepada pengunjung secara langsung.

\section{DAFTAR PUSTAKA}

\section{Referensi Buku dan Jurnal}

AR, D. Sirojudin. (1985). Seni Kaligrafi Islam. Jakarta: Logos.
Panero, Julius. Zelnik, Martin. (2003). Dimensi Manusia dan Ruang Interior. Jakarta: Erlangga.

D K. Ching Francis. (2008). Arsitektur: Bentuk, Ruang, dan Tatanan Edisi ketiga. Ciracas, Jakarta: Erlangga.

Auziny Rahmah. (2015). Perancangan Institut Kaligrafi Islam Internasional Al-Hamidi di Jombang. Skripsi. Malang: Universitas Negeri Maulana Malik.

Tomy Arief. (2010). Galeri Seni Urban Yogyakarta. Tugas Akhir. Surakarta: Universitas Sebelas Maret.

Aghni Ghofarun Auliya. (2014). Estetika Seni Lukis Kaligrafi Karya Syaiful Adnan. Skripsi. Surakarta: Institut Seni Indonesia Surakarta..

Gusmian, Islah. (2003). Kaligrafi Islam: Dari Nalar Seni Hingga Simbolisme Spiritual. Jurnal Al-Jami'ah. 41(1): 108-108,126-129.

Okta, Arta. dkk. (2012). Galeri Seni Rupa Kontemporer di Semarang. Jurnal IMAJI. 1(2):230.

Triyanto. (2014). Pendidikan Seni Berbasis Budaya. VIII(1): 230.

Karamina, Rayi. Setijanti, Purwanita. (2013). Pengaplikasian Tema Ekspresif pada Pusat Ekspresi Seni di Surabaya. JURNAL SAINS DAN SENI POMITS. 2(2):G-31.

Iskandar, Irma. dkk. (2013). Fleksibilitas Sistem Interior pada Selasar Sunaryo Art Space. Jurnal Rekajiva.01(2):3-6, 8-9..

\section{Website}

Nurdiansyah, Rian. (2017). Arsitektur Metafora . Diambil kembali pada 24 maret 2019 dari https://www.scribd.com/document/3549 75977/ARSITEKTUR -METAFORA

http://www.pengertianmenurutparaahli.com/pe ngertian-edukasi/ (diakses pada 25 maret 2019).

http://kasart21.blogspot.com/2018/12/yuk-intip -menariknya-seni-kaligrafi-di.html (diakses pada 2 april 2019).

https://alif.id/read/muhammad-aswar/senikaligrafi-geometri-dan-garis-garis-rindupada-sang-nabi-b213700p/ (diakses pada 2 april 2019)

www.lemka.co.id 